DOI: 10.14451/2.133.33

\title{
О ВОЗМОЖНОСТИ ПРИМЕНЕНИЯ АМЕРИКАНСКОГО ОПЫТА В ЧАСТИ ОТВЕТСТВЕННОСТИ ОРГАНОВ УПРАВЛЕНИЯ И УЧАСТНИКОВ КОРПОРАЦИИ В РОССИЙСКОМ ЗАКОНОДАТЕЛЬСТВЕ
}

\author{
(C) 2019 Милицкая Кристина Николаевна \\ магистр юриспруденции, аспирант \\ Самарский государственный экономический университет, Россия, Самара \\ преподаватель кафедры гражданского права и процесса \\ Оренбургский институт (филиал) Университета имени О.Е. Кутафина (МГЮА), Россия, Оренбург \\ E-mail:123as2012@list.ru
}

В настоящей статье рассматривается американский опыт построения корпоративных правоотношений в области ответственности участников корпораций и ее органов управления. Проводится анализ критериев теста Пауэлла и доктрины «duty of loyalty», возможность заимствования отдельных положений доктрин российским законодательством.

Ключевые слова: добросовестность, корпоративные отношения, ответственность участников корпораций, ответственность директоров.

Российское корпоративное право начало свой путь развития лишь в недавнем прошлом, поскольку в советское время корпоративные отношения имели ограничения и были представлены через призму социализма в виде колхозов и совхозов, хотя даже это представление о существовании корпоративных отношений в советское время вызывает противоречивые мнения у исследователей.

Поэтому при выстраивании основных начал и системы корпоративного права, а также формировании конкретных норм, необходимо обратиться к изучению зарубежного опыта. Поскольку российская правовая система традиционно относится к романо-германской правовой системе, следовало бы обратиться к изучению немецкого права как к одной из наиболее выстроенных систем права.

Между тем, нельзя игнорировать и американское право, относящееся к англосаксонской правовой системе, однако не менее работающее. Многие исследователи могут утверждать о невозможности заимствования американского опыта в построении корпоративных отношений, поскольку американская правовая система построена на прецеденте и главенствующей роли судейского усмотрения при разрешении споров.

Однако если задуматься над тем, что лежит в основе принятия решений российскими судами при рассмотрении дел о привлечении к ответственности органов управления корпорации за причиненные корпорации убытки своими действиями, то мы неминуемо придем к таким категориям как добросовестность, разумность и справедливость. Разве эти категории не должны быть применены судьями с опорой на конкретные обстоятельства дела и проявлением гибкости, для того чтобы решение было действительно добросовестным и справедливым?

Для разрешения данной проблемы необходимо изучить американское корпоративное право в части ответственности органов управления и участников корпораций, условий наступления такой ответственности, а также установить возможность применения отдельных норм права, сформированных в прецедентной системе, к системе континентального права.

Рассмотрим основные положения института ответственности органов управления корпорации по убыткам, причиненным корпорации своими действиями, а также ответственности участников корпорации как лиц, имеющих фактическую возможность определять действия юридического лица в США.

Главенствующая роль в этом институте отводится доктрине «снятия корпоративной вуали», доктрине «alter ego» и доктрине «instrumentality». Менее заметная роль принадлежит доктрине единого коммерческого предприятия и доктрине агентских отношений.

Поскольку доктрина «снятия корпоративной вуали» не отличается четкостью и определенностью, и практика ее применения сильно разнится между штатами и судами, для конкретиза- 
ции появились доктрины «alter ego» и доктрина «instrumentality». Если первая доктрина указывает на то обстоятельство, что участник использует корпорацию как свое «второе я», то вторая основывается на том, что участник использует корпорацию как инструмент для достижения своих собственных целей, пренебрегая интересами самой корпорации. Зачастую в решениях судов нельзя найти ссылку на конкретную доктрину, положения одной доктрины могут использоваться в совокупности с положениями другой, причем такое заимствование положений может быть частичным, и суд может счесть, что оснований для привлечения к ответственности достаточно.

Главную роль при формировании данных доктрин получил тест Пауэлла, который в своем исследовании материалов дел, сформулировал критерии обоснованности «снятия корпоративной вуали» судами.

Тест Пауэлла, который был сформулирован им еще в 1931 г. применительно к ответственности основных обществ по обязательствам дочернего, основан на трех факторах - контроля, противоправности действий и причинно-следственной связи. При этом каждый из этих факторов имеется множество суб-факторов, определяющих признаки самого фактора. Примечательно, что суды при вынесении решений могут посчитать обоснованным «снятие корпоративной вуали», даже при наличии только нескольких суб-факторов в одном факторе, и даже при наличии только одного фактора, если посчитают, что этого достаточно для установления виновности [3].

Доктрина «alter ego» сосредоточена на факторе контроля, для ее применения необходимо доказать, что корпорация и ее участники - по сути, нераздельны. В данном случае корпорация находится не просто под влиянием и управлением ее участников, но и не обладает своей обособленностью, поскольку наблюдается полное единство интересов и имущества.

Фактор контроля устанавливается путем установления чрезмерного контроля над операциями и решениями корпорации участниками, при этом важно установить, что в этом случае пренебрегались интересы и независимость корпорации. Среди суб-факторов оценке подлежат такие обстоятельства как использование одного и того же имущества корпорацией и ее участником - юридическим лицом в ходе осуществления деятельности, осуществление функций руководителей одними и теми же лицами в корпорации и участнике - юридическом лице, осуществление коммерческой деятельности корпорацией исключительно с материнской компанией, а также недостаточная капитализация и др. Последний суб-фактор, однако, вызывает немало дискуссий. В каждом конкретном случае суд должен по своему усмотрению определить, является ли капитализация достаточной, опираясь на концепцию того, что сумма денежных средств на момент учреждения корпорации была соразмерной предполагаемым суммам во исполнение обязательств с учетом характера ее деятельности и предпринимательских рисков. Существует также мнение, что капитализацию нужно усматривать не в уставном капитале корпорации, а в капитале, формирующемся от осуществления деятельности, ради которых была создана корпорация. Недостаточная капитализация в этом случае будет проявляться лишь тогда, когда будет установлен вывод денежных средств из корпорации.

Если вернуться к рассмотрению первой точки зрения в отношении недостаточной капитализации, оцениваемой на момент создания корпорации, то мы неизбежно столкнемся с давней дискуссией о том, необходимо ли увеличить порог минимального уставного капитала юридических лиц или нет. С одной стороны, увеличивая этот минимальный порог, законодатель может обезопасить интересы кредиторов корпорации. Однако тут мы столкнемся с новой проблемой - необходимо будет «заморозить» этот уставный капитал, чтобы корпорация, осуществляя хозяйственную деятельность и неся риски предпринимательства, не смогла растратить этот минимум. С другой стороны, увеличение минимального порога уставного капитала приведет к резкому сокращению числа корпоративных организаций, пострадает интенсивность гражданского оборота.

Некоторые ученые высказывают точку зрения о том, что необходимо создать гибкий уставный капитал, который будет определяться в зависимости от суммы оборота. Так, предлагается установить компаниям с оборотом от 1 до 10 млн. долларов уставный капитал в размере не менее 150000 долларов, компаниям с оборотом от 10 до 20 млн. долларов - не менее 300000 долларов [1]. Предлагается также данный гибкий уставный капитал устанавливать, учитывая специфику 
деятельности корпорации, больший по размеру должен быть предусмотрен, к примеру, для корпораций занимающимися крупными строительными работами, медицинской деятельностью и т.д. Важно отметить, что российское законодательство отчасти учитывает этот момент, устанавливая повышенный размер уставного капитала для компаний, осуществляющих, например, банковскую деятельность.

Существует также мнение, согласно которому недостаточная капитализация корпорации, связанная с выводом денежных средств и имущества корпорации участником, относится не к фактору контроля, а к фактору противоправных действий.

В целом, фактор противоправных действий связан с установлением совершения противоправных или недобросовестных действий участником в ущерб юридическому лицу. Среди суб-факторов данного фактора выделяются совершение сделок с заинтересованностью (между корпорацией и участником на крайне невыгодных условиях для корпорации), несоблюдение корпоративных формальностей (отсутствие решений собраний, документированного выпуска акций в пользу основного общества), введение в заблуждение (обещание кредитору гарантированного исполнения обязательств третьим лицом).

И, наконец, третий фактор теста Пауэлла фактор причинно-следственной связи требует, чтобы контроль и противоправные действия участника корпорации привели к убыткам, которые требуется возместить. Фактор причинно-следственной связи зачастую не требует доказывания, поскольку суды презюмируют наличие данного фактора, если только не будет доказано иное.

У доктрины «снятия корпоративной вуали», несмотря на ее высокую применимость судами, существуют и противники. Так, утверждается, что судам предоставляется слишком широкий круг правомочий для судейского усмотрения при определении не только наличия факторов, но и их достаточности для привлечения к ответственности. Предлагается формализовать в законодательных нормах неправомерность передачи активов и установить преимущественные права при банкротстве [4]. Естественно, что и у предложений С. Бейнбриджа есть свои противники, которые указывают на то, что суды потеряют гибкость при разрешении споров и приведет к злоупотреблениям участников корпорации, которые при заключении сделок будут планировать сделки так, чтобы избежать ответственности, причиняя при этом ущерб самой корпорации.

Нельзя сказать, что доктрины коммерческой концессии и агентских отношений составляют достойную конкуренцию доктрине «снятия корпоративной вуали» в применении, поскольку их применение носит эпизодический характер.

Согласно доктрине единого коммерческого предприятия большее значение имеет не соблюдение формальностей в отношении связи корпорации и ее участников, а установление единой бизнес стратегии всей корпоративной структуры. Здесь важно объединение ресурсов для достижения общей цели, и если в ходе заключения сделок для такой цели был причинен ущерб кредиторам, то к ответственности может быть привлечено любое из этих юридических лиц.

Доктрина агентских отношений предполагает, что не требуется установления критерия противоправных действий участника корпорации. При разрешении споров, суды, применяя данную доктрину, указывают на чрезмерный контроль для обоснования наличия агентских отношений, не ссылаясь при этом на факторы доктрины «снятия корпоративной вуали», хотя по своей сути, такие случаи можно было отнести к случаям применения однофакторного теста Пауэлла.

Рассматривая вопрос о применимости американского опыта в российском законодательстве, справедливо отмечается, что судебное усмотрение, основанное на нормах закона и разъяснениях высших судов, придает правоприменительной практике ту самую гибкость, необходимую для справедливого разрешения споров по существу, позволяет в полной мере реализовать важнейший юридико-методологический подход приоритета существа над формой и избежать чрезмерного формализма при разрешении споров [1].

В отношении же органов управлении корпорации (назовем эту категорию субъектов правоотношений обобщенно - директор) в американском праве действует доктрина «duty of royalty». Ее основной посыл - недопущение обогащения директоров за счет корпорации, недопущение использования возможности получить прибыль лично, а делать это в интересах корпорации, а 
также запрет совершения действий в своих личных интересах или в интересах третьих лиц в ущерб интересам корпорации.

В российском законодательстве в отношении директоров установлено аналогичное требование - директора должны действовать добросовестно. Конкретный перечень действий директора, раскрывающий принцип добросовестности при осуществлении их деятельности, содержится в Постановлении Пленума Высшего Арбитражного суда № 62 от 30.07.2013 г. «О некоторых вопросах возмещения убытков лицами, входящими в состав органов юридического лица».

Особый интерес в изучении вопроса привлечения к субсидиарной ответственности контролирующих лиц представляет не столь давно принятое Постановление Пленума Верховного Суда РФ от 21.12.2017 г. № 53 «О некоторых вопросах, связанных с привлечением контролирующих лиц должника к ответственности при банкротстве». Отмечается, что механизм, раскрытый в постановлении, является исключительным механизмом восстановления нарушенных прав кредиторов.

Одним из самых примечательных положений постановления является указание на то, что осуществление фактического контроля над должником возможно вне зависимости от наличия (отсутствия) формально-юридических признаков аффилированности, суд должен установить степень вовлеченности лица, привлекаемого к субсидиарной ответственности, в процесс управления должником, проверив насколько значимым было его влияние на принятие существенных деловых решений относительно деятельности должника. В целом, круг признаков аффилированности стал гораздо шире. В частности, п. 7 постановления устанавливает, что контролирующим лицом может быть признано лицо, извлекшее существенную выгоду в виде увеличения активов, которая не могла бы образоваться, если бы действия руководителя должника соответствовали закону, в том числе принципу добросовестности. Можно ли таким лицом признать контрагента должника, который, возможно, и не знал о недобросовестных действиях директора должника? Представляется, что такая ситуация вполне возможна.

Окончательная редакция постановления включила в себя положение, изначально предложенное Федеральной налоговой службой России и в дальнейшем поддержанное судьями, о том, что директор не утрачивает статус контролирующего лица, если он руководил бизнесом по указанию скрытого владельца. Таким образом, разрешился давно возникший вопрос об ответственности фиктивных директоров.

Кроме того, в соответствии с п. 24 постановления к субсидиарной ответственности может быть привлечен и главный бухгалтер, если причиной объективного банкротства стали их совместные с руководителем действия.

Рассматриваемое постановление, несомненно, составлено на высоком уровне, имеет все шансы стать работающим инструментов в вопросах защиты нарушенных прав кредиторов, однако, возникает закономерный вопрос - до какой степени возможно зарегулировать механизм привлечения к ответственности, чтобы не размыть окончательно институт ограниченной ответственности юридического лица? Представляется, что должен быть соблюден очень хрупкий баланс частных и публичных интересов в обществе. Насколько принятое постановление отвечает этому требованию покажет судебная практика, которая только находится на стадии формирования после принятия данных разъяснений высшей судебной инстанции.

Подводя итог всему вышесказанному, хотелось бы отметить, что рассматриваемые доктрины имеют свою специфику в зависимости от того, в законодательстве какой страны они находят свое выражение. В американском праве доктрина снятия корпоративной вуали и доктрина лояльности имеют широкое применение, поскольку в правовом регулировании доминирует судейское усмотрение, которое предоставляет большие возможности использования средств правовой защиты в соответствии с правом справедливости.

Российское законодательство же относится к странам с романо-германской правовой системой, в которой прецеденту не отводится правообразующая роль. Тем не менее, законодательство устанавливает, что ответственность органов управления корпораций может наступить только в случае недобросовестного и неразумного поведения. Устанавливая эту самую добросовестность и разумность, судьи неминуемо сталкиваются с тем, что необходимо учитывать обстоятельства каждого конкретного случаи и рассматриваемого дела. Это значит, что мы неминуемо сталкиваемся с необходимостью обра- 
щения к доктрине снятия корпоративной вуали и доктрине лояльности. Поскольку институт снятия корпоративной вуали в настоящее время все еще находится на этапе становления в рамках законодательных положений, обратиться к опыту правопорядка, в котором эта доктрина и зародилась, представляется наиболее разумным.

Судебное усмотрение, основанное на нормах закона и разъяснениях высших судов, придает правоприменительной практике ту самую гибкость, необходимую для справедливого разрешения споров по существу, позволяет в полной мере реализовать важнейший юридико-методологический подход приоритета существа над формой и избежать чрезмерного формализма при разрешении споров.

\section{Библиографический список}

1. Захаров А.Н. Привлечение основного общества к солидарной ответственности по обязательствам дочернего общества: Дис. ... канд. юрид. наук.- Москва, 2015, с. 122-124.

2. Жукова Ю.Д. Противоправность поведения руководителя хозяйственного общества как основание ответственности за причинение обществу убытков в результате совершения сделок от его имени: Дис. ... канд. юрид. наук.- Москва, 2013, с. 78-79.

3. Frederick J. Powell, Parent and Subsidiary Corporations (1931), https://openlibrary.org/books/OL18472548M/ Parent_and_subsidiary_corporations

4. Stephen M. Bainbridge, Abolishing Veil Piercing, 26 Journal of Corporation law, 2001, https://papers.ssrn.com/sol3/ papers.cfm?abstract_id=291060 